\title{
Assessment of Bottled Drinking Water Quality in Baghdad Local Market by Some Chemical and Biological Parameters
}

\author{
Ahmed Kh. Kadhim, Noor Y. Salih and Sabah O. Hamad \\ Central Environmental Laboratory, Ministry of Health and Environment, Iraq \\ Corresponding author: ahmed_khudair@yahoo.com
}

\begin{abstract}
The aim of this work is to study different parameters of bottled drinking water that affect the health of people of Baghdad city. To perform this target, seventeen bottled samples were collected from local markets which were different bottles size and trade markets. The samples were analyzed physical, chemical and biological factors that influence water quality of the bottled water. The physical and chemical tests of bottled water showed that the mean value of $\mathrm{pH}$ ranged from 6.968.5, Total Dissolved Solids (TDS) 8-166 ppm, Total Hardness (TH) 22-178 ppm, Calcium $\left(\mathrm{Ca}^{++}\right)$ 0.0-35 ppm, Magnesium $\left(\mathrm{Mg}^{++}\right)$0.0-30 ppm, Chloride $\left(\mathrm{Cl}^{-}\right)$0.0-27 ppm, sodium $\left(\mathrm{Na}^{+}\right)$0.0-25 ppm, potassium $\left(\mathrm{K}^{+}\right)$0.0-4.5 ppm, Electrical Conductivity $(\mathrm{Ec}) 16-332 \mu \mathrm{s} / \mathrm{cm}$. All samples were within the permissible limits for Iraqi criteria and standards for bottled water. The biological parameters include: total plate count, total coliform, fecal coliform, E.coli and yeast\& fungi. The failure percentages of samples were $23.5,11.7,11.7,11.7$ and $11.7 \%$ respectively.
\end{abstract}

[DOI: 10.22401/ANJS.00.1.10]

Keywords: bottled drinking water, physical parameters, chemical parameters biological parameters, national Iraqi standard.

\section{Introduction}

The availability of good quality drinking water is very important for prevention of diseases and for maintaining the quality of life for humans, [1]. Water quality deals with the physical, chemical and biological characteristics in relation to all other hydrological properties, [2].

The human dietary requirement for water is estimated to be approximately two liters per day for a mean adult. The regular intake of adequate amounts of water is essential in the maintenance of good health and well-being, [3]. However, the most important attribute of drinking water that has to be assured and maintained is its safety and quality to ensure that it is safe for human consumption, [4].

The nature and form of drinking-water standards may vary among countries and regions. There is no single approach that is universally applicable. Approaches that may work in one country or region will not necessarily transfer to other countries or regions. It is essential that each country reviews its needs and capacities in developing a regulatory framework, [5].

It is very essential and important to test the water before it is used for drinking. Water must be tested for different physical and chemical parameters. Selection of parameters for testing of water is solely depends upon for what purpose we going to use that water and what extent we need quality and purity. Water does contain different types of floating, dissolved, suspended and microbiological as well as bacteriological impurities, [6].

\section{Materials and methods}

The physical and chemical parameters assessed in this study were:

\section{pH}

$\mathrm{pH}$ values were measured by wtw $7110 \mathrm{PH}$.

\section{Total Dissolved Solids (TDS) and (Ec) Electrical Conductivity}

Ec and TDS values were measured by wtw 7110 Ec.

\section{Total Hardness as $\mathrm{CaCO}_{3}$}

A buffer solution (about 1-2 mL of weak alkaline $\left(\mathrm{NH}_{4}\right)$ ) was added to $50 \mathrm{~mL}$ of water sample. Usually $1 \mathrm{~mL}$ will be sufficient to give a $\mathrm{pH}$ of 10.0 to 10.1 then an appropriate amount of dry-powder indicator (Erichrome Black T) formulation was added, titrated slowly against standard EDTA, with continuous stirring, until the last reddish tinge 
disappears. Add the last few drops at 3 to 5 seconds intervals. At the endpoint the solution normally is blue, [7].

\section{Calcium $\left(\mathrm{Ca}^{+2}\right.$ as $\left.\mathrm{CaCO}_{3}\right)$}

A strong alkaline (about $2 \mathrm{~mL}$ of $((\mathrm{NaOH})))$ was added to $50 \mathrm{~mL}$ of water sample, (usually $2.0 \mathrm{~mL} \mathrm{NaOH}$ solution will be sufficient to produce a $\mathrm{pH}$ of 12 to 13) then an appropriate amount of dry-powder indicator (Meroxide) was added, the mixture was titrated slowly against standard EDTA, with continuous stirring, at the endpoint the colour will be purple, the endpoint was checked by adding 1 to 2 drops of titrant in excess to make certain that no further color change occurs, [7].

\section{Magnesium $\left(\mathrm{Mg}^{+2}\right.$ as $\left.\mathrm{CaCO}_{3}\right)$}

A calculated magnesium was estimated as the difference between hardness and calcium as $\mathrm{CaCO} 3$, [7] by equation:

$\mathrm{Mg}(\mathrm{mg} / \mathrm{L})=\left[\left(\right.\right.$ Total Hardness as $\left.\mathrm{CaCO}_{3}\right)-$

$$
\left.\left(\mathrm{Ca}^{+2} \text { as } \mathrm{CaCO}_{3}\right)\right] \times 0.243
$$

\section{Potassium $\left(\mathbf{K}^{+}\right)$}

Potassium was Determined in either a direct-reading or internal-standard type of flame photometer at a wavelength of 766.5 nm.

\section{Sodium $\left(\mathrm{Na}^{+}\right)$}

Sodium was determined by flame emission photometry at $589 \mathrm{~nm}$.

\section{The microbial method}

The microbiological parameters assessed in this study were: the total plate count (T.P.C)/ $1 \mathrm{ml}$ by pour plate method, the most probable number of total coliform (M.P.N. of TC)/ $100 \mathrm{ml}$ by multiple tube fermentation, the most probable number of fecal coliform (M.P.N. of FC)/ $100 \mathrm{ml}$ by multiple tube fermentation, the most probable number of $E$. coli (M.P.N. of E. coli)/ $100 \mathrm{ml}$ by multiple tube fermentation. In addition, the yeast \& fungi / $100 \mathrm{ml}$ by filtration method. These parameters are frequently used as indicators of the bacteriological quality of drinking and bottled water, and numerous bacteriological studies of drinking water employ a combination of two or more of these tests [8, $9,10]$.

\section{Results}

\section{Physical and chemical results}

pH: The maximum and minimum $\mathrm{pH}$ values were 8.5 and 6.96 respectively, with the mean of $\mathrm{pH}$ value for all samples 7.7 Table (1). All samples were showed acceptable $\mathrm{pH}$ value when compared with the national Iraqi standard for bottled water (6.5-8.5) [11] and International Bottled Water Association (IBWA) [12,13].

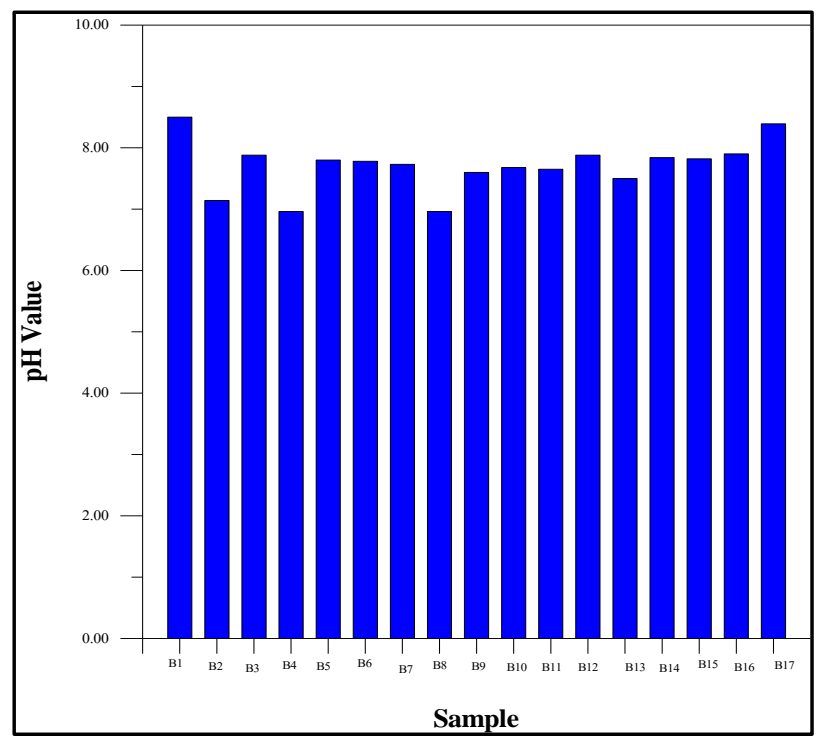

Fig.(1) pH values as a function of water samples.

\section{1- Total dissolved solids (TDS):}

The maximum and minimum TDS value were 166 and 8 ppm respectively, with the mean value 58.79 ppm Table (1). All samples showed acceptable TDS value compared with national Iraqi standard for bottled water (0-250) ppm.

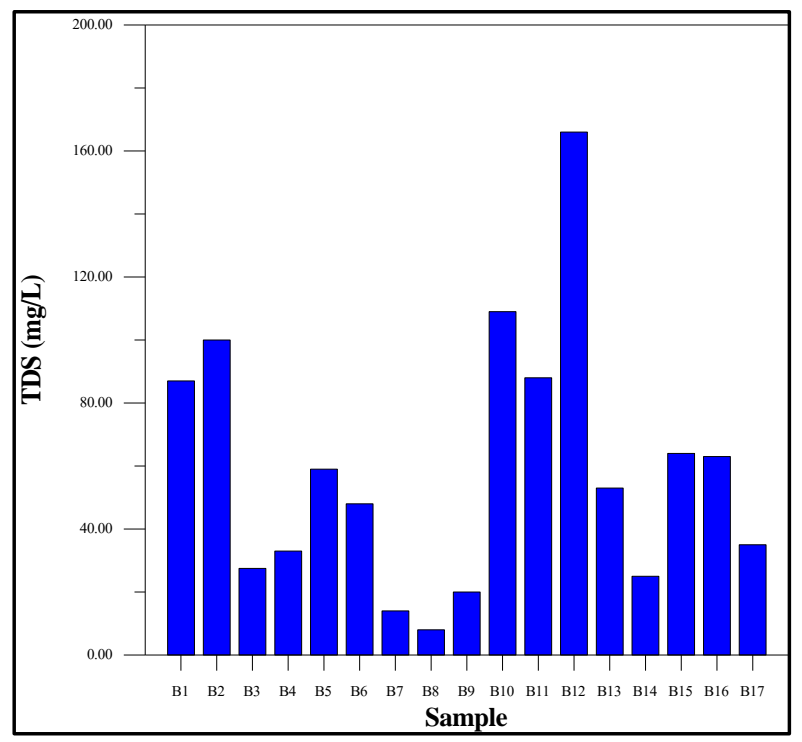

Fig.(2) TDS values as a function of water samples. 


\section{2- Total Hardness (TH) as $\mathrm{CaCO}_{3}$ :}

The maximum and minimum $\mathrm{TH}$ values were 178 and 22 ppm respectively, with mean value $76.69 \mathrm{ppm}$ Table (1). All samples showed acceptable $\mathrm{TH}$ value to the national Iraqi standard for bottled water (0-300) ppm.

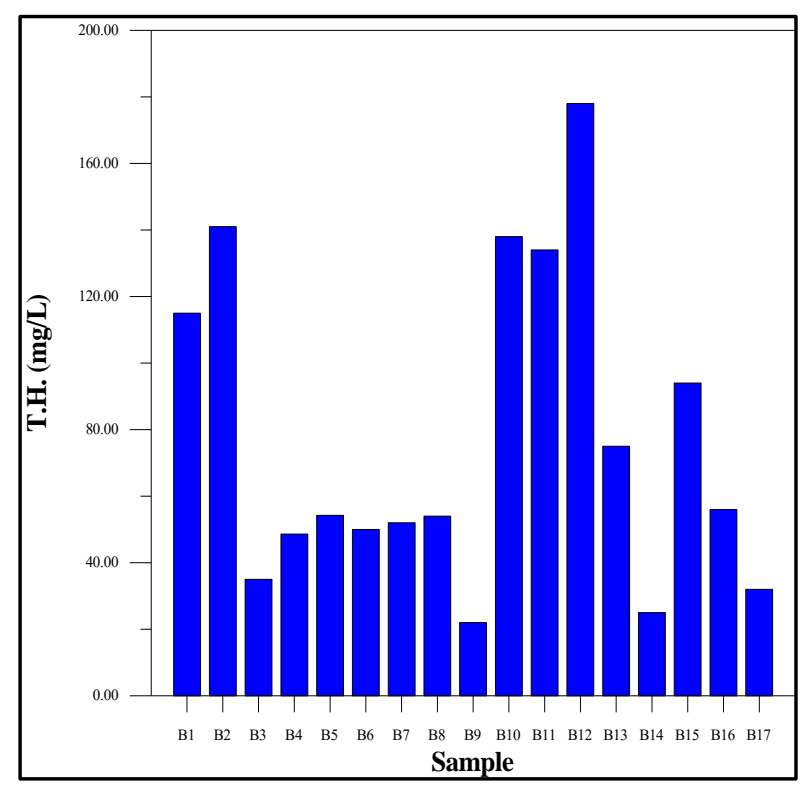

Fig.(3) Concentration of $\mathrm{TH}$ as $\mathrm{CaCO}_{3}$ ( $\mathrm{mg} / \mathrm{L})$ as a function of water samples.

\section{3- Calcium $\left(\mathrm{Ca}^{+2}\right.$ as $\left.\mathrm{CaCO}_{3}\right)$ :}

The maximum and minimum $\mathrm{Ca}$ values were 35 and N.D ppm respectively, with mean Ca value 10.58 ppm Table (1). All samples were acceptable $\mathrm{Ca}$ value compared with national Iraqi standard for bottled water (0-75) ppm.

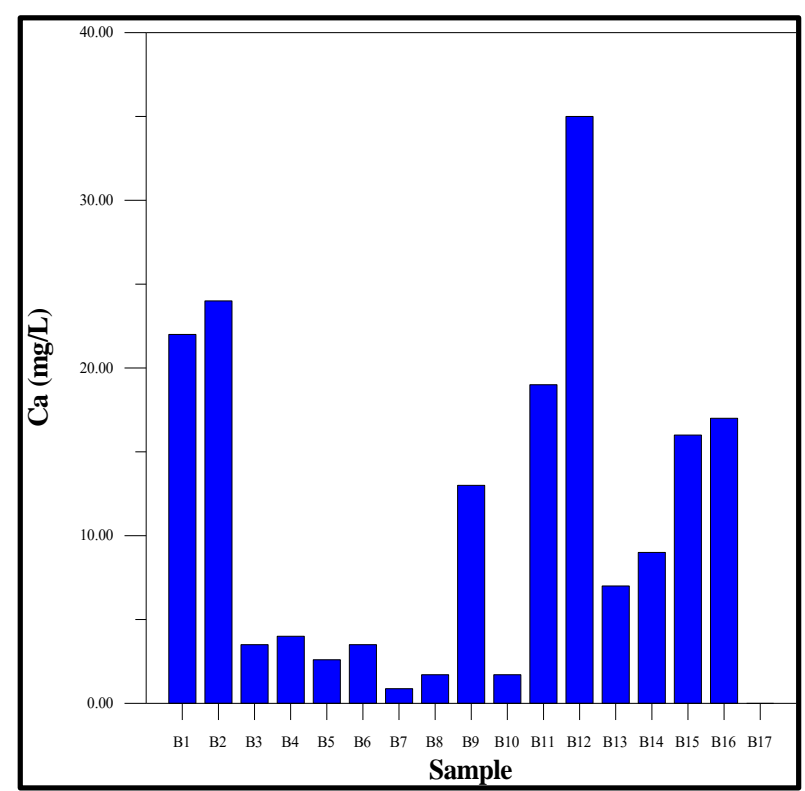

Fig.(4) Concentration of Ca as $\mathrm{CaCO}_{3}$ (mg/L) as a function of water samples.

\section{4- Magnesium $\left(\mathrm{Mg}^{+2}\right.$ as $\left.\mathrm{CaCO}_{3}\right)$ :}

The maximum and minimum $\mathrm{Mg}$ values were 30 and N.D ppm respectively, with the mean of $\mathrm{Mg}$ value $13.02 \mathrm{ppm}$ Table (1). All samples were acceptable $\mathrm{Mg}$ value compared with national Iraqi standard for bottled water (0-30) ppm.

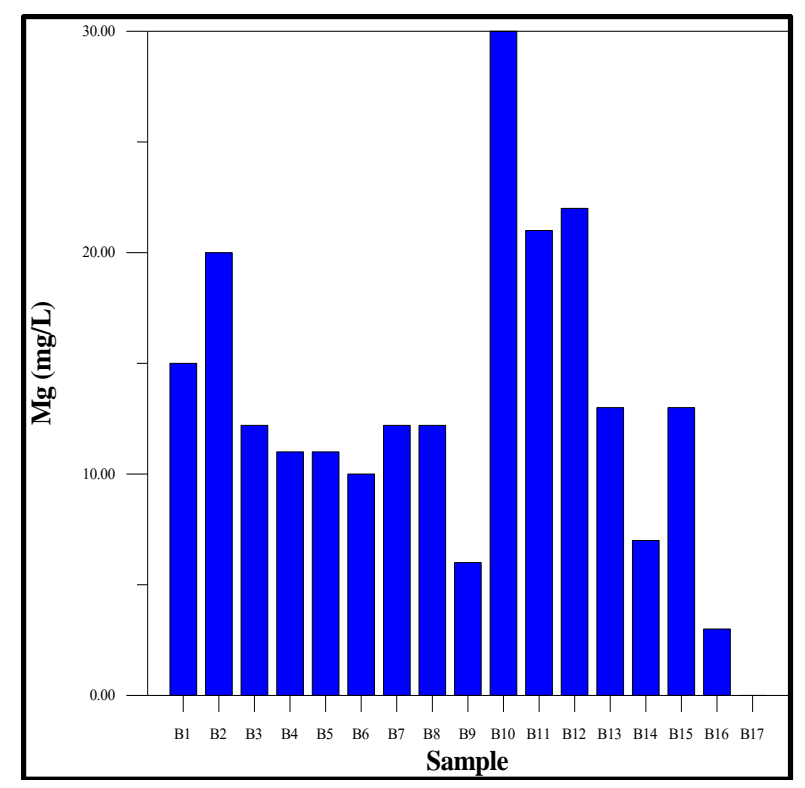

Fig.(5) Concentration of $\mathrm{Mg}$ as $\mathrm{CaCO}_{3}$ $(\mathrm{mg} / \mathrm{L})$ as a function of water samples.

\section{5- Cl:}

The maximum and minimum $\mathrm{Cl}$ values were 27 and N.D ppm respectively, with the mean of $\mathrm{Cl}$ value $8.4 \mathrm{ppm}$ Table (1). All samples showed acceptable $\mathrm{Cl}$ value compared with national Iraqi standard for bottled water (0-250) ppm.

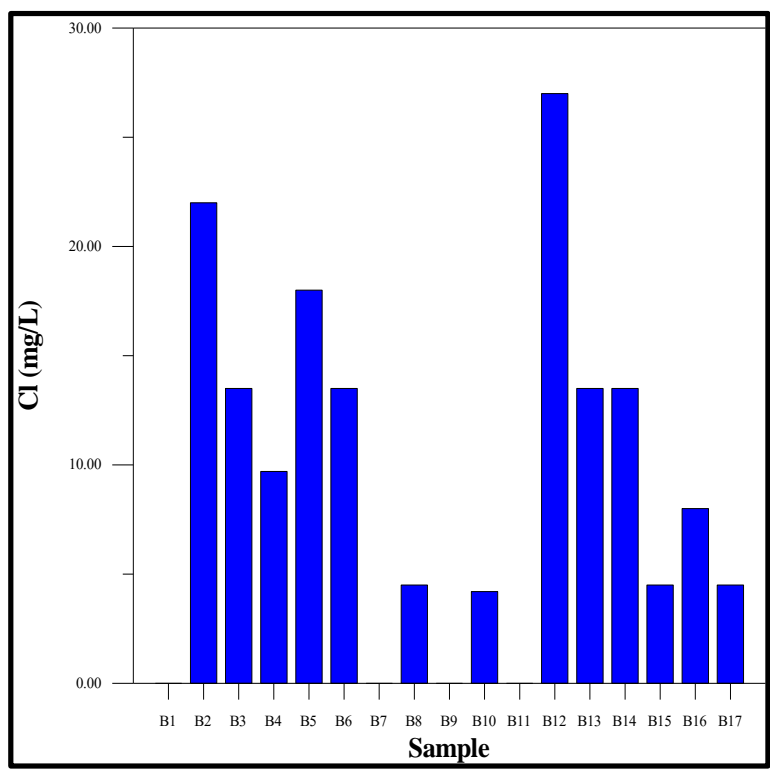

Fig.(6) Concentration of $\mathrm{Cl}(\mathrm{mg} / \mathrm{L})$ as a function of water samples. 


\section{6- Sodium $\left(\mathrm{Na}^{+}\right)$:}

The maximum and minimum $\mathrm{Na}$ value were 25 and N.D ppm respectively, with the mean of Na value 8.04 ppm Table (1).

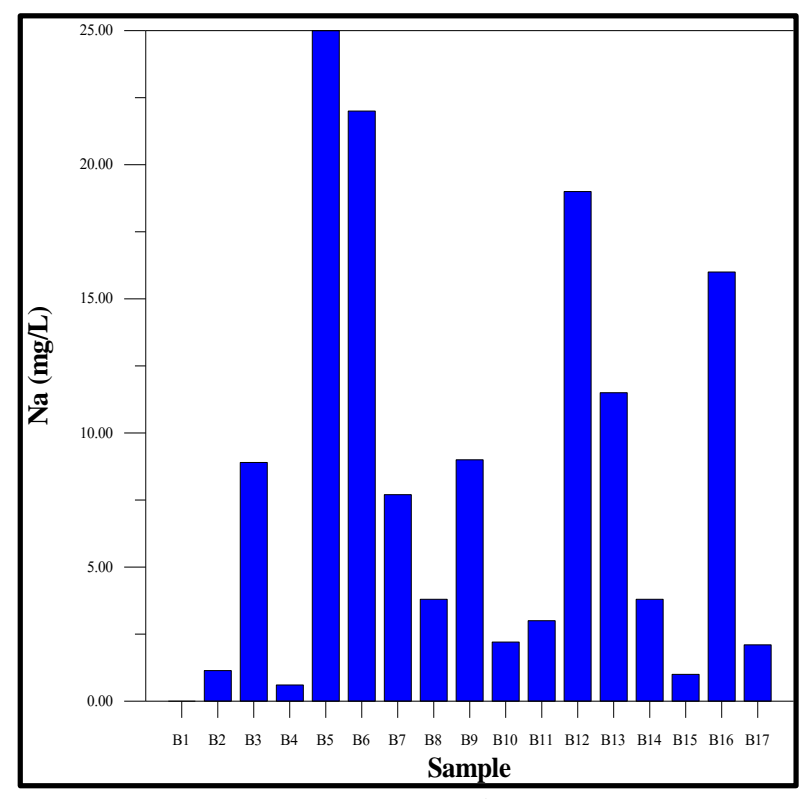

Fig.(7) Concentration of $\mathrm{Na}(\mathrm{mg} / \mathrm{L})$ as a function of water samples.

\section{Potassium $\left(\mathbf{K}^{+}\right)$:}

The maximum and minimum $\mathrm{K}$ value were 4.5 and N.D ppm respectively, with the mean of $\mathrm{K}$ value $0.86 \mathrm{ppm}$ Table (1).

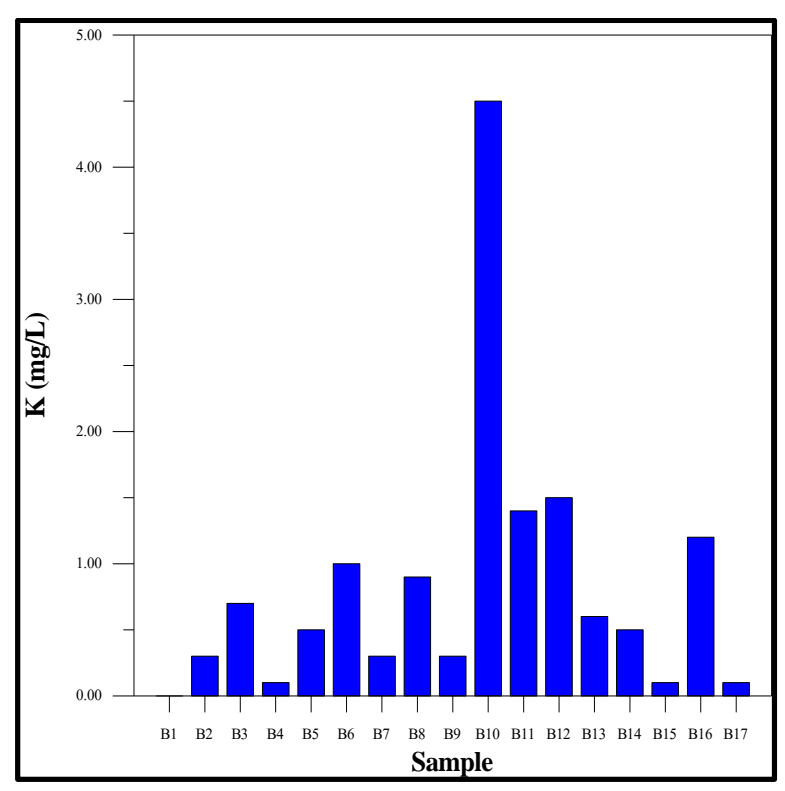

Fig.(8) Concentration of $\mathrm{K}(\mathrm{mg} / \mathrm{L})$ as a function of water samples.

\section{7- Ec:}

The maximum and minimum Ec values were 332 and $16 \mu \mathrm{s} / \mathrm{cm}$ respectively, with the mean of Ec value $117.5 \mu \mathrm{s} / \mathrm{cm}$ Table (1). All samples showed acceptable EC value compared with national Iraqi standard for bottled water (500-1000) $\mu \mathrm{s} / \mathrm{cm}$.

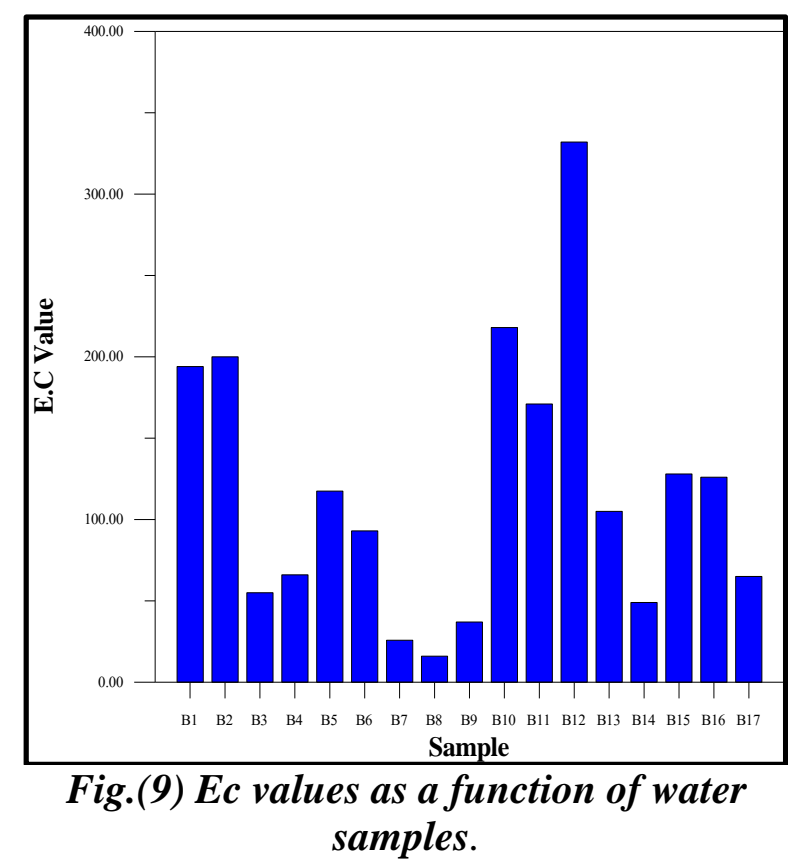

When compared the result with national Iraqi standard for bottled water within allowed limits so it compatible with previous studies [14-15] some of inorganic toxic like heavy metals and organic matter most studied to give a clear review for bottled drinking water and most give it a permissible limits in national Iraqi standard for bottled water, the maximum value showed that bottled volume $20 \mathrm{~L}$ give upper of others but also under national Iraqi standard for bottled water.

\section{Microbial Results}

The results of microbiology observed that five samples were exceeding the allowable limits according to Iraqi Criteria and Standards for bottled drinking water with failure percentage $29.2 \%$ from all examined samples. These results included TPC / $1 \mathrm{ml}$, M.P.N of total coliform / $100 \mathrm{ml}$, M.P.N of fecal coliform / 100ml, M.P.N of E. coli / $100 \mathrm{ml}$, yeast \& Fungi / $100 \mathrm{ml}$ with failure percentage $23.5,11.7,11.7,11.7$ and $11.7 \%$ respectively Table (2). These failure percentage occurred especially of the large bottled container may due to re-used of the container and don't care about cleaning of the container.

The national Iraqi standard for bottled water doesn't contain permissible limits to yeast and fungi but the WHO criteria limit is zero. In this study two of bottled sample were 
contain yeast and fungi therefore must examine this test as routine analysis for bottled drinking water.

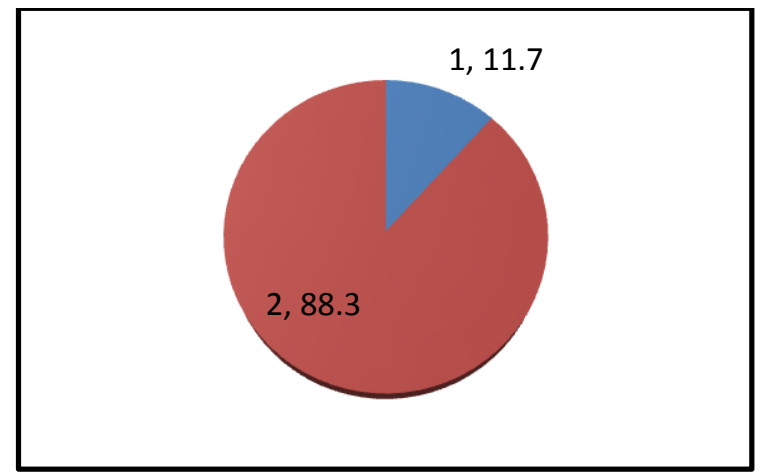

Fig.(10) Failure percentage of M.P.N of T.C/100 ml from all examinated samples.

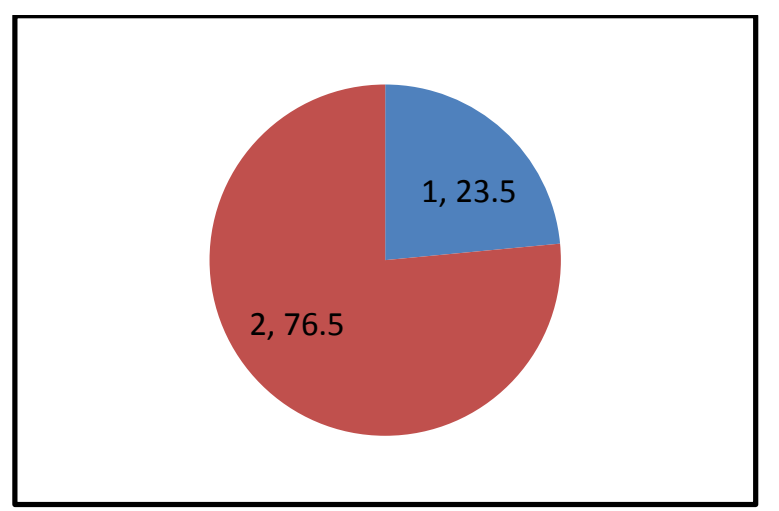

Fig.(11) Failure percentage of T.P.C./ $1 \mathrm{ml}$ from all examinated samples.

Table (1)

The Mean, maximum and minimum value of pH, Ec, total hardness, $\mathrm{Ca}, \mathrm{Mg}, \mathrm{Cl}, \mathrm{Na}, \mathrm{K}$ and TDS in bottled water samples.

\begin{tabular}{||c||c||c||c||c||c||c||c||c||c||}
\hline Sample & PH & EC & T.H & Ca & Mg & Cl & Na & K & TDS \\
\hline \hline B1 & 8.5 & 194 & 115 & 22 & 15 & N.D & N.D & N.D & 87 \\
\hline \hline B2 & 7.14 & 200 & 141 & 24 & 20 & 22 & 1.14 & 0.3 & 100 \\
\hline \hline B3 & 7.88 & 55 & 35 & 3.5 & 12.2 & 13.5 & 8.9 & 0.7 & 27.5 \\
\hline \hline B4 & 6.96 & 66 & 48.6 & 4 & 11 & 9.7 & 0.6 & 0.1 & 33 \\
\hline \hline B5 & 7.8 & 117.4 & 54.2 & 2.6 & 11 & 18 & 25 & 0.5 & 59 \\
\hline \hline B6 & 7.78 & 93 & 50 & 3.5 & 10 & 13.5 & 22 & 1 & 48 \\
\hline \hline B7 & 7.73 & 25.8 & 52 & 0.87 & 12.2 & N.D & 7.7 & 0.3 & 14 \\
\hline \hline B8 & 6.96 & 16 & 54 & 1.7 & 12.2 & 4.5 & 3.8 & 0.9 & 8 \\
\hline \hline B9 & 7.6 & 37 & 22 & 13 & 6 & N.D & 9 & 0.3 & 20 \\
\hline \hline B10 & 7.68 & 218 & 138 & 1.7 & 30 & 4.2 & 2.2 & 4.5 & 109 \\
\hline \hline B11 & 7.65 & 171 & 134 & 19 & 21 & N.D & 3 & 1.4 & 88 \\
\hline \hline B12 & 7.88 & 332 & 178 & 35 & 22 & 27 & 19 & 1.5 & 166 \\
\hline \hline B13 & 7.5 & 105 & 75 & 7 & 13 & 13.5 & 11.5 & 0.6 & 53 \\
\hline \hline B14 & 7.84 & 49 & 25 & 9 & 7 & 13.5 & 3.8 & 0.5 & 25 \\
\hline \hline B15 & 7.82 & 128 & 94 & 16 & 13 & 4.5 & 1 & 0.1 & 64 \\
\hline \hline B16 & 7.9 & 126 & 56 & 17 & 3 & 8 & 16 & 1.2 & 63 \\
\hline \hline B17 & 8.39 & 65 & 32 & N.D & N.D & 4.5 & 2.1 & 0.1 & 35 \\
\hline \hline Mean & 7.7 & 117.5 & 76.69 & 10.58 & 13.02 & 8.4 & 8.04 & 0.86 & 58.79 \\
\hline \hline Maximum & 8.39 & 332 & 178 & 35 & 32.8 & 27 & 25 & 4.5 & 166 \\
\hline \hline Minimum & 6.96 & 16 & 22 & 0 & 0 & 0 & 0 & 0 & 8 \\
\hline \hline
\end{tabular}

Table (2)

The biological results of TPC, TC, FC, E. coli, yeast and fungi and the Failure percentage of bottled water samples.

\begin{tabular}{|c||c||c||c||c||c||c||}
\hline Sample & $\begin{array}{c}\text { T.P.C.I } \\
\text { 1ml }\end{array}$ & $\begin{array}{c}\text { M.P.N } \\
\text { of } \\
\text { T.C/100 } \\
\text { ml }\end{array}$ & $\begin{array}{c}\text { M.P.N } \\
\text { of } \\
\text { F.C/100 } \\
\text { ml }\end{array}$ & $\begin{array}{c}\text { M.P.N } \\
\text { of } \boldsymbol{E} \text {. } \\
\text { coli/100 } \\
\text { ml }\end{array}$ & $\begin{array}{c}\text { Yeast } \\
\text { \&fungi// } \\
\mathbf{1 0 0 m l}\end{array}$ & Resultes \\
\hline \hline B1 & Zero & Zero & Zero & Zero & Zero & Acceptable \\
\hline \hline B2 & Zero & Zero & Zero & Zero & Zero & Acceptable \\
\hline \hline B3 & Zero & Zero & Zero & Zero & Zero & Acceptable \\
\hline \hline B4 & $\mathbf{1 7 0}$ & Zero & Zero & Zero & $\mathbf{1 5 0}$ & Un acceptable \\
\hline \hline B5 & Zero & Zero & Zero & Zero & Zero & Acceptable \\
\hline \hline B6 & Zero & Zero & Zero & Zero & Zero & Acceptable \\
\hline \hline B7 & Zero & Zero & Zero & Zero & Zero & Acceptable \\
\hline \hline B8 & Zero & Zero & Zero & Zero & Zero & Acceptable \\
\hline \hline B9 & Zero & Zero & Zero & Zero & $\mathbf{5 0}$ & Un acceptable \\
\hline \hline B10 & Zero & Zero & Zero & Zero & Zero & Acceptable \\
\hline \hline B11 & Zero & Zero & Zero & Zero & Zero & Acceptable \\
\hline \hline B12 & Zero & Zero & Zero & Zero & Zero & Acceptable \\
\hline \hline B13 & Zero & Zero & Zero & Zero & Zero & Acceptable \\
\hline \hline B14 & $\mathbf{7 5}$ & Zero & Zero & Zero & Zero & Un acceptable \\
\hline \hline B15 & Zero & Zero & Zero & Zero & Zero & Acceptable \\
\hline \hline B16 & $\mathbf{1 1 0}$ & $>\mathbf{2 3}$ & $>\mathbf{2 3}$ & $\mathbf{> 2 3}$ & Zero & Un acceptable \\
\hline \hline B17 & $\mathbf{2 0}$ & $\mathbf{2 . 2}$ & $\mathbf{2 . 2}$ & $\mathbf{2 . 2}$ & Zero & Un acceptable \\
\hline \hline $\begin{array}{c}\text { Failure } \\
\text { percentage }\end{array}$ & $\mathbf{2 3 . 5 \%}$ & $\mathbf{1 1 . 7 \%}$ & $\mathbf{1 1 . 7 \%}$ & $\mathbf{1 1 . 7 \%}$ & $\mathbf{1 1 . 7 \%}$ & $\mathbf{2 9 . 4 \%}$ \\
\hline \hline
\end{tabular}

\section{Acknowledgements}

I would like to thank all central environment laboratory staff for their assisstance advice and thought.

\section{References}

[1] Adewoya B. L., and Oludura A. O., "Efficiency of Morigna Oleifera Seeds Extract on Microflora of Surface and Ground Water", J. of Plant Sciences, 6, 453-438, 2007.

[2] Nasirian, M., "A New Water Quality Index for Environ-mental Contamination Contributed by Mineral Processing: A Case Study of Amang (Tin Tailing) Processing Activity", J. of Applied Sciences, 7 (20), 2977-2987, 2007.

[3] EFSA, "Scientific Opinion on Dietary Reference Values for Water", European Food Safety Authority (EFSA) Journal, 8 (3), 1459, 2010.

[4] Codex Recommended International Code of Practice- Number 48 Code of Hygienic Practice for Bottled/ Package Drinking Waters. Rome: Codex Alimentarius Commission, 2001.

[5] WHO (World Health Organization), "Guidelines for drinking-water quality" 4th ed. Geneva 27, Switzerland, 2011. 
[6] Patil, P. N, Sawant, P. N. and Deshmukh, R. N., "Physico-chemical parameters for testing of water-A review", International J. Environ. Sci., 3 (3):12-43, 2012.

[7] APHA, AWWA and WEF, "Standard Methods for The Examination of Water And Wastewater", $22^{\text {st }}$ edition. Washington, DC: American Public Health Association, American Water Works Association, Water Environment Federation, 2012.

[8] Moe, C. L, Sobsey, M. D., Samsa, G. P., and Mesolo, V., "Bacterial indicators of risk of diarrheal disease from drinking water in the Philippines", Bulletin of the World Health Organization, 69 (3), 305317, 1991.

[9] Marzano, M. A., Ripamonti, B., and Balzaretti, C. M., "Monitoring the bacteriological quality of Italian bottled spring water from dispensers", Food Control, 22 (2), 333-336. doi 10.1016/ j.foodcont.2010.06.014,2011.

[10] Barrell, R. A., Hunter, P. R., and Nichols, G., "Microbiological standards for water and their relationship to health risk", Communicable Disease and Public Health/ PHLS, 3 (1), 8-13, 2000.

[11] National Iraqi Standard for Bottled Water no. IQS 1937/1995.

[12] International Bottled Water Association, the Ibwa model code.

[13] Waleed M. K. Zahid, "quality of local and imported bottled water in Saudi Arabia", J. King Abdul Aziz, 14, 81-104, 2002.

[14] Isam Sh. H. Alzubaidi; Bahaa N. E. Alomosaw, "detection of microbial and chemical contaminants of the plastic bottled drinking waters", J. mracpc, 2 (3), 168-184, 2010. 